\title{
THE IMPACT OF ONLINE LECTURE IN THE COVID-19 PANDEMIC TOWARDS THE COURSE MATERIAL UNDERSTANDING (EXPLORATIVE STUDY TO ISLAMIC EDUCATION POSTGRADUATE STUDENTS AT IAIN SALATIGA)
}

\author{
Aida Dwi Rahmawati*, Abdul Khamid \\ Islamic Education Study Program, IAIN Salatiga, Indonesia \\ *Email: aidadwiinizuka@gmail.com
}

Website: http://jurnal.uin-antasari.ac.id/index.php/jtjik

Received: 6 June 2020; Accepted: 14 December 2020; Published: 17 December 2020

\begin{abstract}
The purpose of this study was to know about student's material understanding because implementation online lectures in pandemic. Then, the positive impact of conducting online lectures and inhibiting factors. This research is qualitative approach. Primary data by Google Form and secondary data by articles. By this, the PAI Postgraduate online implementation strategy utilizing whatsapp group, zoom, and google form. The positive impacts, distant learning prevent outbreaks; flexible lecture time; easier to understand; add insight related to the use of technology; saving cost. While the inhibiting effects is hard to get a comprehensive explanation; difficult signals; lectures who have assignments without explanation; hard to find sources.
\end{abstract}

Keywords: explorative study; learning strategy; online lectures; covid-19

\section{INTRODUCTION}

In this pandemic period, every effort is made so that the life still continues. It can not be denied that covid-19 gives on impact to the process of teaching and learning, in an elementary school until a university. It is not something new to the university to carry out an appropriate lecture in a condition like this. A learning which should be face to face is not longer a must, because of online learning is easier to lecturers or students. Online lecture becomes the choice to lecturers to deliver a course material to the students in the middle of the situation which requires a distance limitation.

As the recommendation from $\mathrm{WHO}$, Indonesian government has instructed to apply teaching and learning at home to help stop the spread of covid-19. It is indirectly also apply a self-quarantine and social distancing (Abdullah : 2020, 44). According to Robert, in his writing, online lecture really depends on a utilization of internet network and technological devices, no exception to covid-19 pandemic period (2020:1). Therefore, the lecturers are expected to play a role in directing the students to mastering any kind of online lecture support platforms (Imam, $2018: 70$ ).

Meanwhile, to the students, Rediana writes that the internet network as a device which is really support in search an e-book or other scientific studies (2010:121). Of course, it gives an easiness to students to be active in searching a source from course material more thoroughly. Beside of that, the online lecture is demanding to adept at using technology devices (Tri, 2007:111) or to operate everything that online based. According to 
Tarbiyah: Jurnal Ilmiah Kependidikan

Vol. 9 No. 2. July - December 2020 (108-115)

DOI: http://dx.doi.org/10.18592/tarbiyah.v9i2.3677

the previous study, it is known that students are more mastering a google classroom and WhatsApp (Nabila, 2020:43). This is very unfortunate, when looking to students' capability which should have considered as a competent in the technology.

Islamic education postgraduate students at IAIN Salatiga has implemented the online lecture since the PSBB policy began to be implemented in Salatiga city. Even it is not a new method of lecturing. In the field, the researcher finds a fact that the students feel the impact of online lecture to the quality of lecture or course material understanding. Through this research, the writer wants to know the implementation process, the impact, until the effectiveness of online lectures to Islamic education postgraduate students at IAIN Salatiga.

\section{RESEARCH METHOD}

The type of research which the researcher uses is qualitative approach (qualitative research), which is a research that aimed to describe and analyze a phenomenon, event, social activity, attitude, trust, perception, people's thought in individual or group (Nana : 2020, 60-61), data is not presented in numeral form but in a word and an overview form (Burhan : 2005, 103). The gathered datas consist of two, which are primary data and secondary data. Primary data is the result of indirectly interview with the postgraduate students at IAIN Salatiga, through the google form questionnaire that deployed via link. While the secondary data is obtained based on the previous study, journals, articles and other scientific papers that related to the subject.

The number of informants in this research consist of 10 Islamic education postgraduate students from class of 2019 which is chosen randomly to find a different data. The criteria of choosing the informant is based on the class and the residence address of the students. From 10 informants are known lived outside of Salatiga city.

Table 1. Data of the Islamic Education Postgraduate Students at IAIN Salatiga

\begin{tabular}{|c|c|c|c|}
\hline No & Name & $\begin{array}{l}\text { Residence } \\
\text { Address }\end{array}$ & Class \\
\hline 1 & Khanifatul Huniayati & Semarang & $\mathrm{C}$ \\
\hline 2 & Rapik & Tangerang & $\mathrm{C}$ \\
\hline 3 & Erna Nur Utami & Purwodadi & $\mathrm{C}$ \\
\hline 4 & Risa & Lasem & $\mathrm{C}$ \\
\hline 5 & Shepta Adi Nugraha & Semarang & $\bar{A}$ \\
\hline 6 & Noor Farida & Kudus & $\mathrm{C}$ \\
\hline 7 & Hendro & Ambarawa & A \\
\hline 8 & Sakbani & Magelang & $\mathrm{C}$ \\
\hline 9 & Dita Atika Sari & Pabelan & B \\
\hline 10 & Roudhotul & Ungaran & $\mathrm{C}$ \\
\hline
\end{tabular}

Amount Respondents per Class

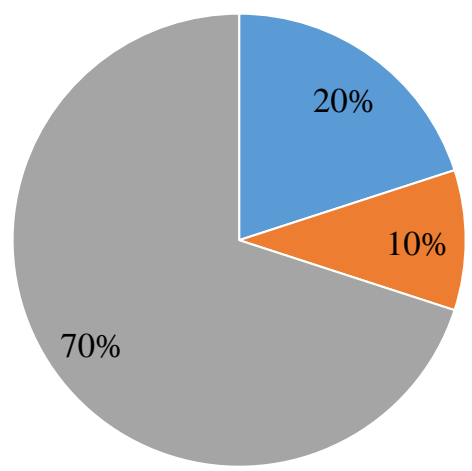
Note:

Picture 1. Respondents per Class

Class A

Class B

Class C 


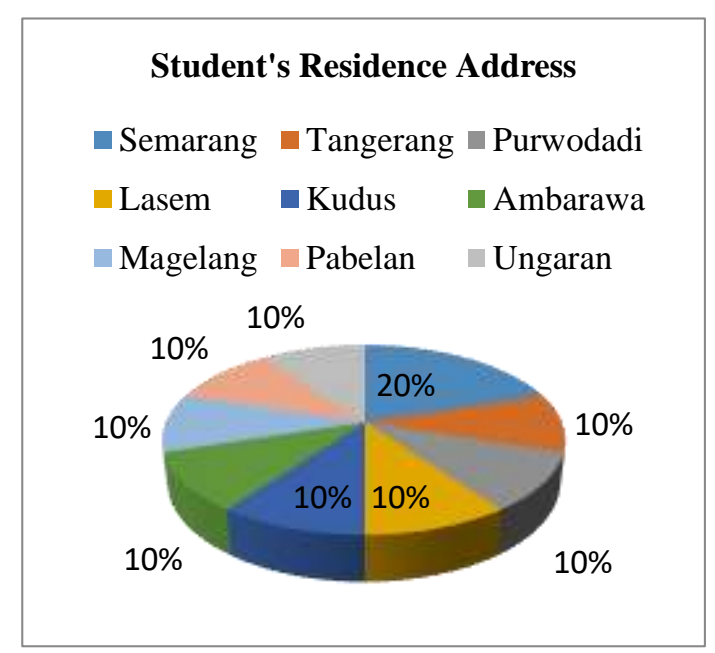

Picture 2. Student's Residence Address

\section{RESULT AND DISCUSSION}

The postgraduate of IAIN Salatiga which place in Salatiga city is one of the higher education institutions that affected by the covid-19. The government's appeal to move a teaching and learning place, which is originally centered at IAIN Salatiga campus is moved to learning from each postgraduate students' home. The purpose of the research is to obtain the information about The Impact of Online Lecture in the Covid-19 Pandemic to the Course Material Understanding (Explorative Study to Islamic Education Postgraduate Students at IAIN Salatiga). All of the interviewees responds are real and it has quoted as what the informants' states.

After doing a research using a questionnaire form (google form), it is obtained some statements that submitted by the informants as follows:

KHS informant gives a respond to a strategy in the implementing lecture in covid-19 situation: "all of the postgraduate students follows lecture from their home".

Other informant says (ENU) the implementation of lecture during the pandemic, "all of the students follows learning activity from home, listen from home through some technology utilization medias such as WAG, google classroom, google forms, zoom meeting".

The statements above gives an overview that in the pandemic period, various strategies are carried out to keep the delivery of course material still goes on with various utilization of technological developments. Other informant gives a respond about the positive and negative impact of the online lecture implementation in the period of covid-19 to the postgraduate students' course material understanding.

RPK gives a respond: "students do not go far to campus, it save the energy and the transportation cost, the time is more free, the online lecture can be done even though students do other activities, it can increase a knowledge of technology development".

In line with the informant above, RSA responds: "students do not go far (home campus) train and get used to do the task properly and correctly".

DAS responds: "the learning is easier and not boring also the time is more flexible and the most interesting thing is students do not miss the course material".

Followed the respond from other informant, HDR: "A distance lecture is still implemented even though it is not followed by the face to face so that students and lecturers are spared from the corona disease with the hope of breaking the deployment of covid-19 soon".

The informant above gives an overview that in the pandemic of covid-19 period, students and lecturers still can do a lecture activity even though with several challenges, it do not weaken students to continue learning well and understand the materials which given by the lecturers, learning from home is a good solution with the hope to break the spread of covid-19. 
Tarbiyah: Jurnal Ilmiah Kependidikan

Vol. 9 No. 2. July - December 2020 (108-115)

DOI: http://dx.doi.org/10.18592/tarbiyah.v9i2.3677

Beside of the positive impact, there are also a negative impact in the implementation of delivering a course material via online. Some of the informants give a statements as follows:

RHDL responds: "not all of the students get a material explanation from the lecturer".

Other opinion is given by RPK: "students are from several region, there are from city and also from village which ahs a difficult signal, so that the online lecture is not effective and students and lecturers should always have an internet data and the increasing of internet data used".

Same as the informant above, NFD responds: "can not deliver a material clearly because of the different environment, less of concentrate, less of responsibility between lectures and students, can not deliver a course clearly, less of friendship with friends".

According to the students, the task that given by lecturers feels so hard. As the opinion from SKN: "sometimes the internet network is less supportive, there are so many tasks than the delivery of material from lecturers, students find it difficult to find a source because of the library is closed".

Overall, all of the postgraduate students feel the positive impacts of the online lecture that given by campus. Nonetheless, as the opinions above which still be found that there are a lacks in the process of the online lecture implementation.

\section{A. The Strategy of the Implementation of Online Lecture in Islamic Education Postgraduate at IAIN Salatiga}

At first, strategy is used in a military world which means as a way of using all of the military force to win a war. According to Wina, strategy in education field can be interpreted as a planning that consist of a sequence of activity that is designed reach a certain goal of education (2014:127).

Then, a lecture which is applied by lecturers will depend on the approach used. While, how to carry out the strategy can be implemented through several learning methods. An effort to carry out a lecture method is a lecturers can decide a technique that they think is relevant with the method and the use of the technique from every lecturers is different to one another.

The covid-19 makes a lot of sector sides have change, including the education field from the very bottom to the highest that have change in learning way, which at the beginning all of the teaching and learning activity is done in the class, now all of it is closed and so all students are also do not come to campus to attend the class anymore. Then, it is change with the online lecture from students' home. In this type of learning, it should have need a readiness between lecturers and students of postgraduate at IAIN Salatiga and a new strategy is implemented in the online lectures which never be done before, but the students; understanding is still noticed and be a priority. The online lecture needs a technology assistance which capable and can be accessed easily, with that then the IAIN Salatiga postgraduate coordinates and decides to do the process of lecture via online with some strategies that given to each lecturers so that the lecture is still continue as what it should be due to the students' course schedule.

As the implementation of lecture conventionally, this lecture needs a strategy so that it can take place optimally. This is known with a good coordination between lecturers and students. Even some lecturers have a particular WhatsApp group, according to the class or the course. While, it has been a 
common habit that every class has a WhatsApp group which consist of the students in it. From the researcher's observation, the explanation above is a form of strategy before the implementation of online lecture is held. The next stage is lecturers can make a use of the situation to start the online lecture.

Table 2. The List of Online Application Used by Students to Online Lecture

\begin{tabular}{|ll|}
\hline \multicolumn{2}{|l|}{ Online Application for Course } \\
\hline 1. & Whatsapp Group \\
\hline 2. & Zoom Meeting \\
\hline 3. & Google Form \\
\hline
\end{tabular}

From the result of the interview is known that students carry out the online lecture with using a media of WhatsApp group, zoom meeting and google form. That three of online applications are proven effective enough to support the online lecture.

Based on the interview result is also known that students tend to be interested to the WhatsApp group media, because it is considered efficient to the internet data used and it has been used as the media to interact. While, from the previous study by Eko, is known that the choice of WhatsApp group as the lecture media also has been said in the previous study (2020:339). Beside of that, the easiness is a reason to the lecturers or students in determining this media in online lectures.

Related to the material understanding, students found it is easy with the allowance of time to them to search an additional information before the evaluation is held. Through the WhatsApp group, students can ask about the task or course material that is not understand yet freely. The students can search the information source through the campus digital library application (pustabiblia), or from google. So that, the course understanding via online lecture can be fulfilled properly.
Even though, the use of WhatsApp is considered easy and effective enough, the reality is students are still have a difficulty to understand the course material which delivered by the lecturers (Afnibar, 2020:79).

Constrained of the network signal that can be disconnected makes the lecture which is use zoom meeting is hampered. It is same when the online course is using Google Form, students complain about a lot of the capacity of the internet data used.

Therefore, postgraduate students during this covid-19 pandemic are still get a learning according to the material that has been told by the lecturers at the beginning of learning contract, beside of being able to help the parents, closer to them (the parents) and of course students still can learn. Students are still confused to the course material, they are allowed to ask when the discussion is ongoing, so that the students' understanding is still continue as it should be, also still have a right to contribute in the learning process now, it is just the place of learning that change during this covid-19 pandemic. This strategy is good enough to keep learning and the spread of science of religion specially the postgraduate students who take Islamic Education Department in the middle of this covid-19 pandemic that rocked, not only in Indonesia, but also the world, with still learning properly.

B. The Positive Impact of the Online Lecture Implementation to the Course Material Understanding at IAIN Salatiga Postgraduate during Covid-19 Pandemic

The covid-19 pandemic which occur now especially in Indonesia, makes almost all of the people in the county really worry even always overshadowed by various information from any sources. Even though, it feels a little bit uncomfortable now, the postgraduate students of IAIN Salatiga still feel a positive 
Tarbiyah: Jurnal Ilmiah Kependidikan

Vol. 9 No. 2. July - December 2020 (108-115)

DOI: http://dx.doi.org/10.18592/tarbiyah.v9i2.3677

impact from online lecture, because every event in this life, there must be a wisdom and positive impact which we can feel in it, from here the writer tries to elucidate from the research result a parts of the positive impact from the covid-19 pandemic to the postgraduate students of IAIN Salatiga.

First: a distance lecture can help a prevention of covid-19 because there is no meeting directly, it is follow the advice from government to stay at home, work from home and learn from home. Second, the lecture's time is more flexible. Third, the course material is easier to understood, this felt by most of postgraduate students because there is an unlimited time to communicate and the lecturers still explain in detail so that the students can listen and hear what the course theme is. Fourth, adding insight which relate to the use of technology or application, with this plague, it gives a chance to the postgraduate students to know more about the world of technology as the media to gain a knowledge in implementing a lecture, it does not meeting directly, but the learning process is still continue with the help of media technology. Fifth, saving transportation cost, because students should not come to campus to attend the class, students only need to stay at home, open the phone and laptop and they can attend the class.

\section{The Negative Impact of the Online Course Implementation to the Course Material Understanding at IAIN Salatiga Postgraduate during the Covid-19 Pandemic}

Indonesia is one of the country which also get an impact of covid-19 pandemic that occur in almost all around the world, the covid-19 pandemic cause Indonesia also takes some appeals to the public, such as a Work from Home (WFH), and online lecture that implemented in almost of the institutions in Indonesia. According to the students; view, online lecture is one of the new method which is not commonplace yet to use in Indonesia's college.

Based on the survey, it found that there are some obstacle in the online lecture implementation, however in every learning process there should be found the positive and negative impact, even more in the education field that never done before in the learning process, students need to adapt more about the use of learning media that based on technology, from here the writer tried to elucidate from the research review about the negative impact in the online course implementation towards IAIN Salatiga's postgraduate students: First, geographical position. Not all of the students get an explanation fully because of when the online lecture occurs, it is difficult to reach the limited signal. Second, internet signal. The lecture is less effective because of the lack of the internet signal. The online lecture implementation can not be separated from internet network, the students' condition do not live in the place that has adequate signal yet. To attend the learning process, sometime some of the students should be out of the house with the hope to get a better internet signal. Third, monotonous learning. It still be found a lecturers who give a task without an explanation, this is felt by some students, lecturers only send a summary about the material, then ask students to read and do the task without a material explanation before. Fourth, information source. Constrained in search a source from book because the library is closed also felt by some students who have a hobby is go to library to increase a reading reference covid-19 pandemic prevent the students to come to library because of it is closed and does not serve borrowing books.

Overall, the impact of the covid-19 pandemic is felt by all of the postgraduate students, there are the positive impacts of 
Tarbiyah: Jurnal Ilmiah Kependidikan

Vol. 9 No. 2. July - December 2020 (108-115)

DOI: http://dx.doi.org/10.18592/tarbiyah.v9i2.3677

online lecture that given by campus. But, from all of that also has the obstacle as the opinion above that there are still found an obstacle in the process of online learning base implementation.

\section{CONCLUSION}

From the elucidation above, the writer concludes that The Impact of Online Lecture in the Covid-19 Pandemic Period to the Course Material Understanding (Explorative Study to the Islamic Education Postgraduate Students at IAIN Salatiga). The strategy in the online lecture implementation of Islamic Education Postgraduate at IAIN Salatiga is implement the online lecture with using a media of WhatsApp group, zoom meeting, and google form. The three online applications are proven effective enough to support the online lecture implementation. The easiness becomes the reason for lecturers and students to decide a suitable media in online lecture. There are the positive impacts in the online lecture implementation to the course material understanding at IAIN Salatiga Postgraduate during the Covid-19 Pandemic. First: a distance lecture can help a prevention of covid-19 because there is no meeting directly. Second, the lecture's time is more flexible. Third, the course material is easier to understood. Fourth, adding insight which relate to the use of technology or application. Fifth, saving transportation cost. While, the resistor impact in the online lecture implementation to the course material understanding at IAIN Salatiga Postgraduate during the Covid-19 Pandemic are: First, not all of the students get an explanation fully. Second, the lecture is less effective because of the lack of the internet signal. Third, it still be found a lecturers who give a task without an explanation. Fourth, constrained in search a source from book because the library is closed.

\section{REFERENCES}

Abidah, (2020) The Impact of Covid-19 to Indonesian Education and Its Relation to the Philosophy of "Merdeka Belajar", Studies in Philosophy of Science and Education (SiPoSE). 1(1). 44.

Afnibar, PemanfaatanWhatsappsebagai Media

KomunikasiantaraDosendanMahasisw adalamMenunjangKegiatanBelajar. $A l$ Munir:

JurnalKomunikasidanPenyiaran

Islam, Vol 11 Nomor 1 Januari-Juni 2020. 79.

Burhan, Bungin. (2005).Metodologi Penelitian: Format-Format Kuantitatif dan Kualitatif, Surabaya: Airlangga University Press. 103.

Chick, Robert Connor. (2020) Using Technology to Maintain the Education of Residents During Covid-19

Pandemic, Journal of Surgical Education, Maret,https://doi.org/10.1016/j.jsurg.2 020.03.018. 1.

Darmayanti, Tri. (2007). E-Learning pada Pendidikan Jarak Jauh, Jurnal Pendidikan Terbuka dan Jarak Jauh.8(2). 111.

S., Imam Sukwatus.(2018). Dampak Penggunaan Social Learning Network, Jurnal Pendidikan Ekonomi.3(1). 70.

Sanjaya, Wina. (2014).Srategi Pembelajaran Beriorientasi Standar Proses Pendidikan, Jakarta: Kencana Prenada Media Group. 43.

Setiyani, Rediana. (2010) Pemanfaatan Internet sebagai Sumber Belajar, Jurnal JPED.5(2). 121.

Sukmadinata, Nana Syaodih. (2010)Metode Penelitian Pendidikan, Bandung: Remaja Rosdakarya. 161. 
Tarbiyah: Jurnal Ilmiah Kependidikan

Vol. 9 No. 2. July - December 2020 (108-115)

DOI: http://dx.doi.org/10.18592/tarbiyah.v9i2.3677

Yulianto, Eko. Perbandingan Kehadiran Sosial dalam Pembelajaran Daring MengunakanWhatsapp group dan Webinar Zoom Berdasarkan Sudut Pandang Pembelajar Pada Masa Pandemic COVID-19, Jartika, Volume 3 No 2 Juli 2020,339.

Z., Nabila Hilmy.(2020) Persepsi Mahasiswa terhadap Perkuliahan Daring, Jurnal Bisnis dan Kajian Strategi Manajemen.(4)1.41-43. 